\title{
Host factors and typhoid fever-associated intestinal perforation in children in Nigeria
}

\author{
Subhash C. Arya $\cdot$ Nirmala Agarwal
}

Accepted: 18 April 2012/Published online: 31 May 2012

(C) Springer-Verlag 2012

Keywords Salmonella typhi $\cdot$ Host factors - Flagellar antigens · Intestinal perforation · Nigeria $\cdot$ Bacterial genes

\section{To the Editor}

We compliment Nasir et al. [1] for their meticulous study on forecasters of mortality-associated typhoid with an intestinal perforation in Nigeria. The contribution by different host factors, such as MHC and human leukocyte antigen (HLA), that might have been responsible for the occurrence of a high proportion of intestinal perforations in typhoid fever in Nigerian children merits an exploration, and this could be assessed through studies on confirmed cases with and without intestinal perforations.

A genetic association in humans between typhoid fever and MHC class II and III genes was evident in individuals with blood culture-confirmed typhoid fever and control subjects from two distinct geographic locations in southern Vietnam [2]. HLA-DRB1 and HLA-DQB1 alleles the gene that encodes tumor necrosis factor (TNF)-alpha (TNFA [-238] and TNFA [-308], the gene that encodes lymphotoxin-alpha, and alleles of the TNF-alpha microsatellite HLA-DRB1*0301/6/8, HLA-DQB1*0201-3, and TNFA*2 $(-308)\}$ were associated with susceptibility to typhoid fever [2]. On the other hand, HLA-DRB $1 * 04$, HLA-DQB $1 * 0401 / 2$, and TNFA* $1(-308)$ were associated with disease resistance [2]. Furthermore, initial studies on the role of genetic factors in susceptibility to non-alcoholic fatty liver disease point toward an important role of human leukocyte antigen in the pathogenesis of non-alcoholic fatty liver disease [3].

Apart from pulsed field-gel electrophoresis typing (PFGE) of isolates from cases with intestinal perforation [1], their genotypic characterization would be valuable to rule out the presence of abnormal flagellar antigenic components responsible for the intestinal perforations in Nigeria. A S. typhi strain carrying the flagellar antigen variant $\mathrm{H} 1-\mathrm{j}$ was associated with acute appendicitis in a Chinese woman in Hong Kong [4].

Conflict of interest None.

\section{References}

1. Nasir AA, Abdur-Rahman LO, Adeniran JO (2011) Predictor of mortality in children with typhoid intestinal perforation in a Tertiary Hospital in Nigeria. Pediatr Surg Int 12:1317-1321 Epub 2011 May 19

2. Dunstan SJ, Stephens HA, Blackwell JM, Duc CM, Lanh MN, Dudbridge F, Phuong CX, Luxemburger C, Wain J, Ho VA, Hien TT, Farrar J, Dougan G (2001) Genes of the class II and class III major histocompatibility complex are associated with typhoid fever in Vietnam. J Infect Dis 183(2):261-268 Epub 2000 Dec 21

3. Celıkbılek M, Selçuk H, Yilmaz U (2011) A new risk factor for the development of non-alcoholic fatty liver disease: HLA complex genes. Turk J Gastroenterol. 22(4):395-399

4. Lau SK, Woo PC, Chan CY, Woo WL, Woo GK, Yuen KY (2005) Typhoid fever associated with acute appendicitis caused by an H1$\mathrm{j}$ strain of Salmonella enterica serotype Typhi. J Clin Microbiol 43(3):1470-1472
S. C. Arya $(\square) \cdot$ N. Agarwal

Sant Parmanand Hospital, 18 Alipore Road, Delhi 110054, India

e-mail: subhashji@hotmail.com; subhashbhapaji@gmail.com 